\title{
Study on the removal of biodegradable NOM from seawater using biofiltration
}

\author{
$\underline{\text { F. Xavier Simon }}^{1 *}$, Elisabet Rudé ${ }^{1}$, Joan Llorens ${ }^{1}$, Sylvie Baig ${ }^{2}$
}

${ }^{1}$ Department of Chemical Engineering, University of Barcelona, C/ Martí i Franquès 1, 08028 Barcelona, Spain

${ }^{2}$ Degrémont SA, 183 avenue du 18 juin 1940, 92508 Rueil-Malmaison cedex, France

\begin{abstract}
Despite the low biodegradability of seawater NOM, problems associated with biofouling are common in facilities that handle seawater. In this work, a fixed-film aerobic biofilter is proposed as an effective unit for preventing biofouling in such facilities.

A packed-bed biofilter with an EBCT $=6-11$ min was employed. The results demonstrated that the DOC is reduced by $6 \%$ and the $\mathrm{BOD}_{7}$ is reduced up to $15 \%$. The LC-OCD analysis revealed that biofiltration abates the LMW neutrals and biopolymer fractions by 33 and $17 \%$, respectively. However, the fractionation with UF membrane showed that the biofiltration process is able to degrade the more biodegradable compounds that have molecular weights that are greater than $1 \mathrm{kDa}$ and compounds with molecular weights of less than $1 \mathrm{kDa}$.

After biofiltration, the biological activity measured in terms of ATP removal was reduced by $60 \%$. Finally, a test to evaluate the biofilm formation capacity of a water sample revealed reductions of $\sim 94 \%$ when comparing biofiltered and non-biofiltered seawater. Therefore, a fixed-film aerobic biofiltration process could be a useful treatment for the removal of biodegradable organic matter from seawater and for improving the water quality in terms of less biofilm formation capacity.
\end{abstract}

\footnotetext{
* To whom correspondence should be addressed.

e-mail: xsimon@ub.edu

tel: +34 934020155; fax: +34 934021291
} 
Keywords: Biofiltration; seawater; natural organic matter (NOM); biofouling; biofilter

\section{Nomenclature}

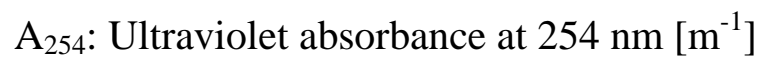

ATP: Adenosine triphosphate $\left[\mathrm{ng}\right.$ ATP L $\left.{ }^{-1}\right]$

$\mathrm{ATP}_{\text {total }}$ : Cellular and free adenosine triphosphate $\left[\mathrm{ng} \mathrm{ATP} \mathrm{L}^{-1}\right]$

$\mathrm{ATP}_{\text {cell }}$ : Cellular adenosine triphosphate $\left[\mathrm{ng} \mathrm{ATP} \mathrm{L}^{-1}\right.$ ]

$\mathrm{ATP}_{\text {free: }}$ Extracellular adenosine triphosphate $\left[\mathrm{ng} \mathrm{ATP} \mathrm{L}^{-1}\right]$

BFC: Biofilm formation capacity $\left[p g\right.$ ATP $\left.\mathrm{cm}^{-2} \mathrm{day}^{-1}\right]$

BFR: Biofilm formation rate $\left[p g\right.$ ATP L ${ }^{-1}$ day $^{-1}$ ]

$\mathrm{BOD}_{7}$ : Biochemical oxygen demand at 7 days $\left[\mathrm{mg} \mathrm{O}_{2} \mathrm{~L}^{-1}\right.$ ]

CMIMA: Mediterranean Center for Marine and Environmental Research

DOC: Dissolved organic carbon $\left[\mathrm{mg} \mathrm{C} \mathrm{L}^{-1}\right]$

EBCT: Empty bed contact time [min]

F-EEM: Fluorescence excitation-emission matrix

HLR: Hydraulic loading rate $\left[\mathrm{m} \mathrm{h}^{-1}\right]$

HMS: High molecular size

HPC: Heterotrophic plate counts [CFU]

LC-OCD: Liquid chromatography coupled with organic carbon detection

LMS: Low molecular size

LMW: Low molecular weight

MF: Microfiltration

MFI: Modified fouling index $\left[\mathrm{s} \mathrm{L}^{-2}\right]$

MWCO: Molecular weight cut-off [kDa] 
$\mathrm{NH}_{4}$ : Ammonia [mg N L ${ }^{-1}$ ]

$\mathrm{N}_{\text {inorg: }}$ Dissolved inorganic nitrogen [mg N L ${ }^{-1}$ ]

$\mathrm{NO}_{2}^{-}$: Nitrite $\left[\mathrm{mg} \mathrm{N} \mathrm{L}^{-1}\right]$

$\mathrm{NO}_{3}{ }^{-}$: Nitrate $\left[\mathrm{mg} \mathrm{N} \mathrm{L}^{-1}\right]$

NOM: Natural organic matter

$\mathrm{N}_{\text {org }}$ : Dissolved organic nitrogen [mg N L $\left.{ }^{-1}\right]$

$\mathrm{N}_{\text {total }}$ : Total dissolved nitrogen [mg N L${ }^{-1}$ ]

RLU: Relative light units

RO: Reverse osmosis

RU: Raman units

$\mathrm{S}_{\text {bead }}$ : Bead surface $\left[\mathrm{cm}^{2}\right]$

SDI: Silt density index $\left[\% \mathrm{~min}^{-1}\right]$

SUVA $_{254}$ : Specific UV absorbance at $254 \mathrm{~nm}\left[\mathrm{~L} \mathrm{mg} \mathrm{C}^{-1} \mathrm{~m}^{-1}\right.$ ]

SWRO: Seawater desalination by reverse osmosis

TDC: Total direct cell counts [cells $\mathrm{mL}^{-1}$ ]

TDS: Total dissolved solids $\left[\mathrm{g} \mathrm{NaCl} \mathrm{L}^{-1}\right]$

UF: Ultrafiltration

UV: Ultraviolet light

\section{Introduction}

Seawater desalination by reverse osmosis (SWRO) has currently emerged as an effective solution to obtain water for human consumption and for industrial and agricultural uses (Schneider and Mastrandrea, 2011). In addition to being used for desalinated water, seawater is also used, e.g., as a coolant in thermal plants (Parkash, 2003; Baker, 2004).

In seawater facilities and particularly in SWRO plants, the most common foulants obtained from SWRO membranes are a combination of both organic and microbial 
deposition (Darton and Fazel, 2001; Xu et al., 2007). Consequently, microorganisms start growing at the expense of dissolved NOM and can develop a biofilm that can cause operational problems (Flemming, 1997; Matin et al., 2011; Griebe and Flemming, 1998; Flemming et al., 1998; Hu et al., 2005). Even with the low and mostly non-biodegradable seawater NOM (Volk et al., 1997; Penru et al., 2011), marine microorganisms are metabolically active (Egli, 2010). In SWRO plants the consequences of fouling include an increase of the membrane resistance coupled with a decrease in water production and water quality. All the above factors have an impact on the total cost of desalinated water (Flemming et al., 2007; Matin et al., 2011).

Pre-treatments in SWRO processes are designed to improve the water quality for stable and sustainable operation (Shon et al., 2008). A considerable number of reports can be found in the literature associated with conventional and membrane pretreatments (Rosberg, 1997; Vial et al., 2003; Halpern et al., 2005; Bonnelye et al., 2008; Voutchkov, 2010, van Hoof et al., 1999; Brehant et al., 2002; Pearce et al., 2004; Kumar et al., 2006; Xu et al., 2007; Lorain et al., 2007; Bonnelye et al., 2008; Shon et al., 2008; Salinas Rodriguez et al., 2009). Nevertheless, dosages of biocides (often chlorinated substances) are the currently employed common strategy to prevent biofouling because biocides can kill nearly all microorganisms. However, debris are not removed from the aqueous phase and they can therefore serve as a substrate for the living microorganisms, which is why the use of biocides is only considered to be a short-term strategy (Flemming, 1997; Schneider et al., 2005). Moreover, microorganisms embedded in a biofilm are more resistant to biocides, which is most likely due to selection in favour of more biocide tolerant bacteria; this property confers a large inertia to the system (Griebe and Flemming, 1998; Chowdhury, 2012). Therefore, the frequent use of biocides results in microorganisms developing resistance to the biocides and may also aggravate the biofouling episodes (Flemming, 2002; Bereschenko et al., 2011).

In this study, it is proposed the use of a fixed-film aerobic biofilter (herein referred to as a biofilter) as an effective unit for preventing organic and biological fouling in SWRO plants and, in general, in facilities that handle seawater. As reported by Rittman (1990), biofilm technology is advantageous when the concentrations of biodegradable substances are low because the retention of cells by attachment allows a considerable accumulation of biomass. Furthermore, as emphasised by Cohen (2001), fixed-film (attached growth) has some advantages related to metabolic 
activities compared with suspended growth. Therefore, aerobic degradation is proposed due to its simplicity and due to the dissolved oxygen content in seawater. The purpose of this study is to evaluate the effectiveness of a biofilter for reducing the biodegradable substances in seawater. Moreover, it is also quantified the reduction of biological activity downstream of the filter.

\section{Materials and Methods}

\subsection{Seawater and pilot biofilter}

The raw seawater was captured from the NW Mediterranean Sea through an open intake that was located $300 \mathrm{~m}$ offshore at a depth of $10 \mathrm{~m}$. No pre-treatment was performed to the raw seawater before it was introduced into the biofilter. Table 1 summarises the characteristics of the raw seawater.

Table 1. Characteristics of the raw seawater

The pilot biofilter was located in the Mediterranean Centre for Marine and Environmental Research (CMIMA, Barcelona). The biofilter was composed of a fixed packed bed of expanded clay (Biolite ${ }^{\circledR}$ L2.7). It was operated downflow, and it was backwashed with both air and water 3 times per week according to Ahmad and Amirtharajah, (1998).

A schematic illustration of the pilot biofilter is presented in Figure $1 a$ while Figure $1 b$ presents an image of the pilot biofilter. Figure $1 c$ presents the detailed characteristics of the filter media (Biolite ${ }^{\circledR} \mathrm{L} 2.7$ ) used in the packed-bed.

The different experimental conditions employed in this study are presented in Table 2. The characteristics of the column and the packed bed are summarised in Table 3.

Figure 1. (a) Schematic illustration of the pilot biofilter; (b) Image of the pilot plant;

(c) Expanded clay - Biolite ${ }^{\circledR}$ L2.7

Table 2. Experimental conditions

Table 3. Characteristics of the column and packed bed 
Colonisation and acclimatisation of the biomass was achieved through a continuous flow of raw seawater for several months. The dissolved oxygen was continuously measured to monitor the full development of the biofilm. It was not necessary to introduce additional oxygen because the amount of dissolved oxygen in the raw seawater was sufficient for the heterotrophic biological activity.

All analyses were performed on the input and output currents of the biofilter. Due to the very small amounts of organic matter that was measured during the experiments of this work, all the glass materials were thoroughly cleaned before use. The glass materials were first soaked in an aqueous $10 \%(\mathrm{~V} / \mathrm{V}) \mathrm{HCl}$ solution for 24 hours and then rinsed with copious amounts of Milli-Q water. Subsequently, the glass materials were covered with aluminium foil and heated to $450{ }^{\circ} \mathrm{C}$ for 4 hours. All the plastic materials were also carefully and thoroughly cleaned before use. Then, these materials were sterilised by autoclaving (QM 4000 SA-202X, Quirumed Spain) for $30 \mathrm{~min}$ at $121^{\circ} \mathrm{C}$.

\subsection{Analysis}

Among the general parameters used to quantify NOM (Matilainen et al, 2011) in this study, the conventional analytical techniques for measuring the $\mathrm{DOC}, \mathrm{BOD}_{7}$ and $\mathrm{A}_{254}$ are used to quantify the NOM at the inlet and at the outlet streams of the biofilter and therefore, to assess the effectiveness of the biofilter in the removal of NOM.

The removal of biodegradable NOM was investigated using a seawater biofilter operating with an empty bed contact time (EBCT) ranging from 6 to $11 \mathrm{~min}$ (corresponding to hydraulic loading rates that range from 5 to $10 \mathrm{~m} \mathrm{~h}^{-1}$ ). Furthermore, to elucidate the mechanisms for the operation of the biofilter for an EBCT $=8.1 \mathrm{~min}$, more accurate techniques used, such as liquid chromatography coupled with organic carbon detection (LC-OCD), fluorescence excitation-emission matrices (F-EEM) and membrane fractionation. Finally, we analysed the evolution of nitrogen compounds in seawater as a result of the biofiltration process and the biofilm formation capacity $(B F C)$ in treated and untreated seawater. 
Dissolved organic carbon (DOC), total nitrogen $\left(\mathrm{N}_{\text {total }}\right)$, ammonia $\left(\mathrm{NH}_{4}^{+}\right)$, nitrite $\left(\mathrm{NO}_{2}^{-}\right)$and nitrate $\left(\mathrm{NO}_{3}^{-}\right)$

The dissolved organic carbon (DOC) analysis consisted of first filtering the sample through a $0.7 \mu \mathrm{m}$ nominal pore GF/F filter (Whatman, Spain), as proposed by Ogawa and Tanoue (2003), and then to prevent inorganic carbon, the samples were acidified with $\mathrm{H}_{3} \mathrm{PO}_{4}$ to a $\mathrm{pH}=2-3(50 \mu \mathrm{L} ; 2 \mathrm{M})$. The samples were stored at $4{ }^{\circ} \mathrm{C}$ in $10 \mathrm{~mL}$ glass vials. The DOC was determined using the high-temperature catalytic oxidation method with a Shimadzu (TOC- $\left.\mathrm{V}_{\mathrm{CSH}}\right)$ analyser. The total dissolved nitrogen $\left(\mathrm{N}_{\text {total }}\right)$ was also analysed using a TN unit according to Álvarez-Salgado and Miller (1998). The inorganic forms of nitrogen (ammonia, $\mathrm{NH}_{4}{ }^{+}$, nitrite, $\mathrm{NO}_{2}{ }^{-}$, and nitrate, $\mathrm{NO}_{3}{ }^{-}$) were measured following the standard procedure described in Grasshoff et al. (1999). A Bran-Luebbe (AA3) auto-analyser was used. The dissolved organic nitrogen $\left(\mathrm{N}_{\text {org }}\right)$ was calculated as the $\mathrm{N}_{\text {total }}$ minus the sum of the forms of inorganic nitrogen $\left(\mathrm{N}_{\text {inorg }}\right)$.

\section{Biochemical oxygen demand at 7 days $\left(\mathrm{BOD}_{7}\right)$ and the biodegradability ratio $\left(\mathrm{BOD}_{7} / \mathrm{DOC}\right)$}

The biochemical oxygen demand at 7 days $\left(\mathrm{BOD}_{7}\right)$ was determined using a previously described method (Simon et al., 2011). This method is an adaptation of the Closed Bottle Method (EPA, 1998) and the Standard Methods 5210 (Standard Methods, 1999), and it uses concentrated autochthonous inoculum. The seawater samples were incubated for 7 days at $20 \pm 1{ }^{\circ} \mathrm{C}$ (Medilow Selecta, Spain), and the dissolved oxygen content was measured before and after incubation with an IntelliCAL ${ }^{\mathrm{TM}}$ LDO probe connected to a HQ40d multimeter (Hach, USA).

The biodegradability of the dissolved carbon was measured from the $\mathrm{BOD}_{7} / \mathrm{DOC}$ ratio in units of $\mathrm{mg} \mathrm{O}_{2} \mathrm{mg} \mathrm{C}^{-1}$ (Liu and Lipták, 1997).

\section{UV absorbance $\left(A_{254}\right)$ and specific $U V$ absorbance at $254 \mathrm{~nm}\left(S U V A_{254}\right)$}

The ultraviolet absorbance at $254 \mathrm{~nm}\left(\mathrm{~A}_{254}\right)$ was measured using a Perkin-Elmer UVVis Lambda 20 spectrophotometer with quartz cuvettes that had a 10-cm path length. The $\mathrm{A}_{254}$ was expressed in $\mathrm{m}^{-1}$. The specific UV absorbance at $254 \mathrm{~nm}\left(\mathrm{SUVA}_{254}\right)$, which is defined as the ratio between $\mathrm{A}_{254}$ and the concentration of DOC (Edzwald and Tobiason, 1999), was also calculated. The $\mathrm{SUVA}_{254}$ was expressed in units of $\mathrm{L}$ $\mathrm{m}^{-1} \mathrm{mg} \mathrm{C} \mathrm{C}^{-1}$. 


\section{Measurements of biological activity}

\section{Adenosine Triphosphate (ATP)}

ATP is a biomolecule that is present in all living organisms, and its concentration in seawater can be used as an indirect measure of the biological activity in seawater (Hammes et al., 2010). The total ATP ( $\left.\mathrm{ATP}_{\text {total }}\right)$ is present in the ecosystem in two different forms, which include cellular ATP $\left(\mathrm{ATP}_{\text {cell }}\right)$ that is directly associated with the living cells and free $\mathrm{ATP}\left(\mathrm{ATP}_{\text {free }}\right)$ that is dissolved in the media and not contained in the cells, which is called extracellular ATP.

$\mathrm{ATP}_{\text {total }}$ and $\mathrm{ATP}_{\text {free }}$ were quantified using the BacTiter-Glo ${ }^{\mathrm{TM}}$ Microbial Cell Viability Assay (Promega Biotech Iberica, Spain) and a GloMax ${ }^{\circledR}$ 20/20 luminometer (Promega Biotech Iberica, Spain). The samples were first filtered through a $0.22 \mu \mathrm{m}$ filter (to retain bacterial cells) before measuring the $\mathrm{ATP}_{\text {free. }}$ The $\mathrm{ATP}_{\text {cell }}$ was indirectly determined by subtracting the $\mathrm{ATP}_{\text {free }}$ from the $\mathrm{ATP}_{\text {total }}$. The measurements were performed by mixing $100 \mu \mathrm{L}$ of the seawater sample with $100 \mu \mathrm{L}$ of an ATP reagent in an Eppendorf tube. The mixture was agitated with an orbital mixer at room temperature for $3 \mathrm{~min}$, and after $30 \mathrm{~s}$, the luminescence signal was recorded, which was measured as relative light units (RLU). The RLU values were converted to ng ATP $L^{-1}$ using ATP standard dilutions (A3377, Sigma-Aldrich). All the ATP analyses were performed in triplicate.

\section{Biofilm formation capacity (BFC)}

A test has been established to evaluate the biofilm formation capacity (BFC) in seawater. The assay is based on the biofilm formation rate (BFR) described elsewhere (van der Kooij et al., 1995a). The BFC test consists of a glass non-porous bead chain (bead surface area $=28.3 \mathrm{~mm}^{2}$ ) that is immersed in continuously flowing water in a vessel $(10 \times 12 \times 15 \mathrm{~cm})$ (see Figure 2$)$, and the growth of biofilm on the glass beads is recorded over time in terms of the ATP concentration. Periodically, a pearl of the chain was carefully removed and analysed for its ATP content. The pearls were placed in an Eppendorf tube that contained $100 \mu \mathrm{L}$ of phosphate buffer $(\mathrm{pH}=7.0)$, and then $200 \mu \mathrm{L}$ of an ATP reagent was added. After mixing for 3 minutes, $200 \mu \mathrm{L}$ of the supernatant was collected and the luminescence signal (in RLU) after 30 seconds was recorded. Finally, the RLU values were converted to ATP content. The BFC is expressed as pg ATP $\mathrm{cm}^{-2} \mathrm{day}^{-1}$. 
Figure 2. Schematic of the BFC monitor

\section{Liquid Chromatography coupled with Organic Carbon Detection (LC-OCD)}

Liquid chromatography coupled with organic carbon detection (LC-OCD) allows the pool of NOM to be separated into major fractions of different sizes and chemical functionalities and to quantify these fractions on the basis of organic carbon (Huber et al., 2011). The fractions obtained with this analysis are biopolymers, humic substances, building blocks, low molecular weight (LMW) neutrals, and LMW acids (Table 4).

Table 4. Composition of the LC-OCD fractions

\section{Fluorescence Excitation-Emission matrices (F-EEM)}

Approximately 50\% of NOM is fluorescent (Beck and Royal Society of Chemistry, 1993). In this study, excitation wavelengths were varied from 220 to $470 \mathrm{~nm}$, and the emission wavelengths were varied from 280 to $580 \mathrm{~nm}$. The fluorescence intensities were corrected by normalising with the Raman spectra of water according to Lawaetz and Stedmon (2009) and subtracting the signal of Milli-Q water.

The excitation and emission data are presented in the form of a fluorescence excitation-emission matrix (F-EEM) according to the fluorescent regions proposed by Chen et al. (2003) (see Table 5).

Table 5. Fluorescence regions (according to Chen et al., 2003)

\section{Membrane fractionation}

Samples of seawater before and after biofiltration were fractionated using a ceramic nanofiltration membrane with a molecular weight cut-off (MWCO) of $1 \mathrm{kDa}$ (TAMI, France) in the tangential-flow mode.

The fraction that can pass through the membrane, which is also referred to as the permeate, is composed of NOM that has molecular weights less than $1 \mathrm{kDa}$ (Amon and Benner, 1996; Ogawa and Tanoue, 2003; Kaiser and Benner, 2009). Therefore, 
the permeate is the low molecular size fraction (LMS) (Equation 1). Then, to fulfil the mass balance, the fraction that has molecular weights greater than $1 \mathrm{kDa}$, which represents the high molecular size (HMS) fraction, was calculated using Equation 1. Note that DOC appears in Equation 1 and 2, but the same calculations are performed for $\mathrm{BOD}_{7}$ and $\mathrm{A}_{254}$.

$\mathrm{DOC}_{\mathrm{LMS}}=\mathrm{DOC}_{\text {permeate }} \quad[$ Equation 1]

$\mathrm{DOC}_{\mathrm{HMS}}=\mathrm{DOC}_{\text {seawater }}-\mathrm{DOC}_{\text {permeate }} \quad$ [Equation 2]

The $\mathrm{SUVA}_{254}\left(\mathrm{~A}_{25} / \mathrm{DOC}\right)$ and biodegradability $\left(\mathrm{BOD}_{7} / \mathrm{DOC}\right)$ ratios were also calculated using the previously described parameters.

\section{Results and discussion}

\subsection{DOC, $A_{254}$, BOD, turbidity, biodegradability and SUVA $\mathbf{A}_{254}$ for different EBCT}

Biofiltration was performed at three different EBCTs, including 5.7, 8.1 and 11.3 min. Table 1 presents the values of DOC, $\mathrm{A}_{254}, \mathrm{BOD}_{7}, \mathrm{SUVA}_{254}$ and $\mathrm{BOD}_{7} / \mathrm{DOC}$ obtained at the inlet and outlet streams of the biofilter for each EBCT. The removals for each parameter were also calculated and are presented in Table 6.

The first observation from Table 6 is the low content of organic matter in seawater $\left(\right.$ DOC $\left.=0.93-1.13 \mathrm{mg} \mathrm{C} \mathrm{L}^{-1}\right)$ compared to natural freshwater $\left(1-30 \mathrm{mg} \mathrm{C} \mathrm{L}^{-1}\right)$, (Jaffe et al., 2008; Baghoth et al., 2008). Additionally, the low values of $\mathrm{BOD}_{7}(1.00-$ $\left.1.11 \mathrm{mg} \mathrm{O}_{2}\right)$ and $\mathrm{BOD}_{7} / \mathrm{DOC}\left(0.98-1.17 \mathrm{mg} \mathrm{O}_{2} \mathrm{mg} \mathrm{C}^{-1}\right)$ reveal that the seawater contains only a small fraction of biodegradable matter. Furthermore, the values of SUVA $_{254}<1$ reveal the lower hydrophobic character of NOM (Edzwald and Tobiason, 1999). These results are consistent with those previously obtained by Penru et al. (2011). However, although most NOM observed in seawater is resistant to microbial oxidation (Ogawa et al., 2001), the biological filtration with EBCTs from values as low as 5.7 to $11.3 \mathrm{~min}$ allows the removal of $\mathrm{DOC}, \mathrm{A}_{254}$ and $\mathrm{BOD}_{7}$ ranging from 4 to $15 \%$. In the investigated EBCT range, the $\mathrm{SUVA}_{254}$ at the inlet and at the outlet streams of the biofilter remain almost invariable due to no preferential removal 
of UV absorbing substances. As expected, the biodegradability ( $\left.\mathrm{BOD}_{7} / \mathrm{DOC}\right)$ at the output of the biofilter is always small in comparison to the input.

Low consumptions of DOC have also been reported by other authors (Sndergaard and Worm, 2001), and it has been observed that these consumptions are significantly affected by the source of NOM (Hozalski et al., 2001). The DOC in seawater is primarily recalcitrant and at most $19 \%(\mathrm{SD}=12 \%)$ of this DOC can be used by heterotrophic microorganisms (Søndergaard and Middelboe, 1995).

Table 6. Inlet and outlet concentrations of the different analytical parameters and the removals attained in the biofiltration process

Note that the NOM removed by the biofiltration process corresponds to the easily biodegradable fraction, as evidenced by the fact that the removal of DOC is almost independent of the EBCT in the investigated range. Presumably, this fraction of NOM is the one that can cause biofouling in downstream processes (Carlson and Amy, 1997).

The hydraulic loading rates (HLR), which are directly associated with the EBCT, ranged from 5 to $10 \mathrm{~m} \mathrm{~h}^{-1}$, and it does not appear to have any effect on the removal of NOM, as reported elsewhere (Carlson and Amy, 1998).

The results obtained in a seawater environment enable a classification of the overall NOM depending on the lability of the carbon (Carlson and Ducklow, 1996; Ogawa and Tanoue, 2003). Therefore, seawater NOM can be classified in three fractions that are named labile, semi-labile and recalcitrant. The use of a biofilter can remove the more labile fraction in few minutes (most likely less than $5 \mathrm{~min}$ ). These labile compounds are those that support bacterial growth (Hozalski et al., 1995). The semilabile fraction is susceptible to be removed depending on the applied EBCT. Finally, the refractory fraction cannot be removed by biofiltration and some type of preoxidation process could be required to remove this fraction (Lamsal et al., 2011).

\subsection{Nitrogen}

The measurements of the concentration of organic and inorganic nitrogen at the inlet and the outlet streams of the biofilter revealed the preferential use of organic nitrogen during the biological activity of the biofilter ( 
Figure 3). It was observed that $18 \%$ of organic nitrogen $\left(\mathrm{N}_{\mathrm{org}}\right)$ was consumed in the biofilter, whereas the amount of inorganic nitrogen $\left(\mathrm{N}_{\text {inorg }}\right)$ remained almost constant. These results are consistent with those published by Cherrier et al. (1996).

Figure 3. Concentration of $\mathrm{N}_{\text {inorg }}$ and $\mathrm{N}_{\text {org }}$ at the inlet and outlet streams of the biofilter operating at $\mathrm{EBCT}=8.1 \mathrm{~min}$

Figure 4 provides a breakdown of the inorganic nitrogen composition. Nitrate $\left(\mathrm{NO}_{3}{ }^{-}\right)$ is the predominant $(70 \%)$ species in seawater. Furthermore, the amount of nitrate in the outlet of the biofilter is greater than in the inlet due to the biological oxidation of $\mathrm{NH}_{4}{ }^{+}$and $\mathrm{NO}_{2}^{-}$by the nitrification reactions (Hellinga et al., 1999). Therefore, autotrophic nitrifying bacteria are also present in the filter. However, due to the low concentration of ammonia in seawater, it may be concluded that autotrophic biomass represents only a small part of the total biomass of the biofilter.

Figure 4. Inorganic nitrogen $\left(\mathrm{NH}_{4}{ }^{+}, \mathrm{NO}_{2}{ }^{-}\right.$, and $\left.\mathrm{NO}_{3}{ }^{-}\right)$distribution in the inlet and outlet streams of the biofilter operating at $\mathrm{EBCT}=8.1 \mathrm{~min}$

\subsection{Evolution of ATP in the biofiltration process}

Analyses of the ATP concentrations were performed at the inlet and the outlet of the biofilter. It was observed that the biofilter reduces the amount of ATP in seawater by $60 \%$; the concentration of ATP at the outlet was $16 \mathrm{ng} \mathrm{ATP}$ cell $\mathrm{L}^{-1}$ whereas that at the input was $41 \mathrm{ng} \mathrm{ATP}_{\text {cell }} \mathrm{L}^{-1}$ (Figure 5). From the above mentioned ATP concentrations, it is possible to estimate the cell number at both the inlet and outlet of the biofilter. Assuming that a marine cell has an ATP content of $0.5-6.510^{-6} \mathrm{ng}$ ATP (Hamilton and Holm-Hansen, 1967), the active cell number observed at the inlet is 6.3 $10^{6}-8.210^{7}$ cells $\mathrm{L}^{-1}$, whereas in the outlet the active number of cells is $2.510^{6}-3.2$ $10^{7}$ cells $\mathrm{L}^{-1}$. However, the amount of ATP trapped in the biofilter during the period between two consecutive backwashings is considerably less than the amount of ATP extracted in the backwashing process itself. Therefore, autochthonous biomass is established and developed in the biofilter. 
Figure 5. Concentrations of $\mathrm{ATP}_{\text {cell }}$ and $\mathrm{ATP}_{\text {free }}$ at the inlet and outlet streams of the biofilter operating at $\mathrm{EBCT}=8.1 \mathrm{~min}$.

\subsection{Evolution of LC-OCD in the biofiltration process}

The LC-OCD reveals that seawater has a low content of organic matter that is primarily composed of LMW neutrals, humic substances and building blocks, which represent approximately 90\% of the total DOC (Baghoth et al., 2008; Penru et al., 2011; Simon et al., 2012). All fractions, except the LMW acids, were removed to some extent by the biofiltration process (Figure 6). The maximum removals were achieved for LMW neutrals (33\%), which essentially consist of alcohols, aldehydes, ketones, sugars and amino acids (Huber et al., 2011). In principle, all these compounds can be easily degraded by heterotrophic biomass (Amon et al., 2001). Building blocks were better removed than humic substances (21\% and $9 \%$, respectively), which was most likely because of their lower complexity and greater hydrophilicity (Huck, 1999; Baghoth et al., 2008; Penru et al., 2011). For biopolymers with high molecular weights, the concentration of $64 \mu \mathrm{g} \mathrm{C} \mathrm{L}^{-1}$ in seawater was reduced to $53 \mu \mathrm{g} \mathrm{C} \mathrm{L}^{-1}$ by the biofilter.

Figure 6. Results of LC-OCD for the inlet and outlet streams of the biofilter operating

$$
\text { at } \mathrm{EBCT}=8.1 \mathrm{~min}
$$

\subsection{Membrane fractionation}

The fractionation of the seawater using membranes revealed that the majority of NOM in seawater has a molecular weight that is less than $1 \mathrm{kDa}$ (Figure 7). Therefore, it was observed that $67 \% \mathrm{BOD}_{7}, 90 \% \mathrm{DOC}$ and $77 \%$ of $\mathrm{A}_{254}$ are in this majority fraction, which is consistent with the results published elsewhere (Kaiser and Benner, 2009; Ogawa and Tanoue, 2003; Amon and Benner, 1996; Dittmar and Kattner, 2003; Amon and Benner, 1996; Dittmar and Kattner, 2003). Furthermore, the results reveal that the biodegradability and the aromaticity of seawater contain a greater proportion of high molecular size fraction (HMS) material compared with the total of the DOC. Accordingly, although the LC-OCD analysis revealed that the $L M W$ neutrals fraction was better reduced fraction (see Figure 6), this is only a slight 
fraction of the DOC pool. Therefore, HMS are better degraded than LMS. All these results confirm the size-reactivity continuum model, which suggests that NOM found in HMS is more bioreactive than LMS (Tranvik, 1993; Amon and Benner, 1996; Ogawa and Tanoue, 2003; Kaiser and Benner, 2009).

Figure 7. LMS and HMS fractions distribution at the inlet and outlet streams of the biofilter, expressed in terms of $\mathrm{BOD}_{7}, \mathrm{DOC}$, and $\mathrm{A}_{254}(\mathrm{EBCT}=8.1 \mathrm{~min})$. Note that in the case of the outlet stream, the distribution between LMS and HMS is referred to inlet parameters.

\subsection{Fluorescence excitation-emission matrices}

Figure 8 presents the F-EEM of the seawater at the input and output of the biofilter when the EBCT was 8.1 min. ¡Error! No se encuentra el origen de la referencia.7 shows the accumulated fluorescence intensities, expressed as Raman Units (RU), with their percentage on the five aforementioned groups and the fluorescence reduction due to the biofiltration process.

Figure 8. Density plots of fluorescence intensities for seawater at the input $(a)$ and output $(b)$ of the biofilter $(\mathrm{EBCT}=8.1 \mathrm{~min})$

Table 7. Fluorescence intensity distribution at the inlet and outlet streams of the biofilter and removals operating at $\mathrm{EBCT}=8.1 \mathrm{~min}$

The fluorescence signal from seawater primarily arises from humic and fulvic acids, which represent approximately $90 \%$ of the total observed intensity. All five distinct regions of the fluorescence excitation-emission matrix undergo a reduction in intensity due to the biofiltration process, and the overall reduction is $12 \%$. The highest reduction $(21 \%)$ was observed in region [I], which is primarily composed of aromatic protein-like substances. Aromatic protein-like substances are susceptible to being biologically degraded and are hypothesised to be a principal foulant together with the polysaccharides (Salinas Rodriguez et al., 2009). Furthermore, the tyrosine-like and 
tryptophan-like fluorescence peaks are contained in the protein-like regions, which were first described by Coble (1996) and are characteristic of microbial activity and associated with labile organic matter.

\subsection{Biofilm formation capacity (BFC)}

The potential capacity of seawater to cause biofouling was measured in seawater before and after the biofiltration process. To measure this capability, the BFC assay was used as described above. Figure 9 shows the concentration of ATP over 40 days of the test.

The average concentration of ATP in the biofilm exposed to unfiltered seawater was greater than $100 \mathrm{pg}$ ATP $\mathrm{cm}^{-2} \mathrm{day}^{-1}$. In contrast, the average concentration in the biofilm exposed to the biofiltered seawater was less than $7 \mathrm{pg}$ ATP $\mathrm{cm}^{-2} \mathrm{day}^{-1}$. Therefore, the biofilter is capable of reducing biological activity by approximately $95 \%$.

Figure 9. ATP concentrations on the surface of the beads versus time obtained with the BFC assay performed in the seawater before (inlet) and after (outlet) the biofiltration process $(\mathrm{EBCT}=8.1 \mathrm{~min})$

Vrouwenvelder et al.(2001; 2003) observed that ATP concentrations greater than 100 pg ATP $\mathrm{cm}^{-2} \mathrm{day}^{-1}$, which were measured using the biofilm formation rate (BFR) test, involve problems related to biofouling. Although there are some differences between the BFR and BFC tests (e.g., in the BFR test, the supports are small circular bands, whereas in the BFC test, the supports are beads; furthermore, the hydraulic rates are greater in the BFR tests), the obtained values could be compared.

Using this comparison, in terms of biofouling capacity, it can be stated that the biofiltered seawater is better than treated freshwater (groundwater or river water) (van der Kooij et al., 1995a). However, biofiltration does not appear to reduce the biofouling capacity of seawater to less than $1 \mathrm{pg}$ ATP $\mathrm{cm}^{-2}$ day $^{-1}$, which can be observed in treated freshwaters that have very low contents of easily biodegradable substances (van der Kooij et al., 1995b). 


\section{Conclusions}

A biofilter operated with an EBCT of $5.7-11.3 \mathrm{~min}$ is able to reduce the small amount of biodegradable NOM observed in seawater. These reductions correspond to removals of $\mathrm{DOC}, \mathrm{BOD}_{7}$ and $\mathrm{A}_{254}$ ranging from 6 to $15 \%$.

NOM fractions obtained by LC-OCD analysis in the inlet and outlet of the biofilter have shown reductions through the biofiltration process of 33\% of LMW neutrals, 21 $\%$ of building blocks and $17 \%$ of biopolymers.

NOM fractions obtained by membrane separation in the inlet and outlet of the biofilter have shown that the biofiltration process reduces the molecular weight of the NOM. The percentage of compounds with molecular weights greater than $1 \mathrm{kDa}$ is effectively reduced.

Fluorescent analysis (F-EEM) of seawater has shown the presence of fulvic acid-like substances, humic acid-like substances and aromatic protein-like compounds. Fulvic and humic acid-like substances are more abundant than the aromatic protein-like compounds, but in the biofiltration process, the aromatic protein-like compounds are reduced in a greater proportion than the fulvic and humic acid-like substances.

The organic nitrogen content of seawater is the nitrogen source to fulfil the metabolic processes of the microorganisms that developed in the biofilter. Furthermore, seawater contains a slight quantity of inorganic nitrogen as ammonia, which is almost fully oxidised to nitrate in the biofiltration process.

Biofiltration significantly reduces the ability of seawater to generate a biofilm.

\section{Acknowledgements}

The authors are grateful to the Spanish Ministry of Industry (CDTI) for their financial support within the framework of the Project CENIT: CEN20071039. Furthermore we also want to thanks Dr. C. Marrasé and Dr. E. Berdalet from CMIMA (CSIC, Spain) for the support regarding fluorescence and nutrient analyses. 


\section{References}

Ahmad, R. and Amirtharajah, A. (1998) Detachment of particles during biofilter backwashing. Journal - American Water Works Association 90 (12), 74-85.

Álvarez-Salgado, X. A. and Miller, A. E. J. (1998) Simultaneous determination of dissolved organic carbon and total dissolved nitrogen in seawater by high temperature catalytic oxidation: conditions for precise shipboard measurements. Mar. Chem. 62 (3-4), 325-333.

Amon, R., Fitznar, H., Benner, R. (2001) Linkages among the bioreactivity, chemical composition, and diagenetic state of marine dissolved organic matter. Limnol. Oceanogr. 46 (2), 287-297.

Amon, R. and Benner, R. (1996) Bacterial utilization of different size classes of dissolved organic matter. Limnol. Oceanogr. 41 (1), 41-51.

Baghoth, S. A., Maeng, S. K., Rodriguez, S. G. S., Ronteltap, M., Sharma, S., Kennedy, M. D., Amy, G. L. (2008) An urban water cycle perspective of natural organic matter (NOM): NOM in drinking water, wastewater effluent, storm water, and seawater. Water Science and Technology: Water Supply 8 (6), 701-707.

Baker, R. W. (2004) Membrane technology and applications. Wiley, Chichester, 538.

Beck, A. J. and Royal Society of Chemistry (1993) Organic substances in soil and water: natural constituents and their influences on contaminant behaviour. Royal Society of Chemistry, 
Bereschenko, L. A., Prummel, H., Euverink, G. J. W., Stams, A. J. M., van Loosdrecht, M. C. M. (2011) Effect of conventional chemical treatment on the microbial population in a biofouling layer of reverse osmosis systems. Water Res. 45 (2), 405-416.

Bonnelye, V., Guey, L., Del Castillo, J. (2008) UF/MF as RO pre-treatment: the real benefit. Desalination 222 (1-3), 59-65.

Brehant, A., Bonnelye, V., Perez, M. (2002) Comparison of MF/UF pretreatment with conventional filtration prior to RO membranes for surface seawater desalination. Desalination 144 (1-3), 353-360.

Carlson, C. and Ducklow, H. (1996) Growth of bacterioplankton and consumption of dissolved organic carbon in the Sargasso Sea. Aquat. Microb. Ecol. 10 (1), 69-85.

Carlson, K. H. and Amy, G. L. (1998) BOM removal during biofiltration. Journal American Water Works Association 90 (12), 42-52.

Carlson, K. H. and Amy, G. L. (1997) The formation of filter-removable biodegradable organic matter during ozonation. Ozone: science engineering 19 (2), 179-199.

Chen, W., Westerhoff, P., Leenheer, J., Booksh, K. (2003) Fluorescence excitationemission matrix regional integration to quantify spectra for dissolved organic matter. Environmental Science \& Technology 37 (24), 5701-5710.

Cherrier, J., Bauer, J., Druffel, E. (1996) Utilization and turnover of labile dissolved organic matter by bacterial heterotrophs in eastern north Pacific surface waters. Marine ecology.Progress series 139 (1-3), 267-279. 
Chowdhury, S. (2012) Heterotrophic bacteria in drinking water distribution system: a review. Environ. Monit. Assess. 184 (10), 6087-6137.

Coble, P. (1996) Characterization of marine and terrestrial DOM in seawater using excitation emission matrix spectroscopy. Mar. Chem. 51 (4), 325-346.

Darton, E. G. and Fazel, M. (2001) A statistical review of 150 membrane autopsies. In: Proceedings International Water Conference, 157-163.

Dittmar, T. and Kattner, G. (2003) Recalcitrant dissolved organic matter in the ocean: major contribution of small amphiphilics. Mar. Chem. 82 (1-2), 115-123.

Edzwald, J. and Tobiason, J. (1999) Enhanced coagulation: US requirements and a broader view. Water Science and Technology 40 (9), 63-70.

Egli, T. (2010) How to live at very low substrate concentration. Water Res. 44 (17), $4826-4837$.

EPA (1998) Biodegradability in sea water., OPPTS 835.3160.

Flemming, H., Neu, T., Wozniak, D. (2007) The EPS matrix: the "house of biofilm cells". J. Bacteriol. 189 (22), 7945-7947.

Flemming, H., Tamachkiarowa, A., Klahre, J., Schmitt, J. (1998) Monitoring of fouling and biofouling in technical systems. Water science and technology $\mathbf{3 8}(8-9)$, 291-298.

Flemming, H. (1997) Reverse osmosis membrane biofouling. Experimental Thermal and Fluid Science 14 (4), 382-391. 
Flemming, H. (2002) Biofouling in water systems-cases, causes and countermeasures. Appl. Microbiol. Biotechnol. 59 (6), 629-640.

Grasshoff, K., Ehrhardt, M., Kremling, K., Anderson, L. G. (1999) Methods of seawater analysis. Wiley-VCH, Weinheim etc., 600.

Griebe, T. and Flemming, H. (1998) Biocide-free antifouling strategy to protect RO membranes from biofouling. Desalination 118 (1-3), 153-156.

Halpern, D., McArdle, J., Antrim, B. (2005) UF pretreatment for SWRO: pilot studies. Desalination 182 (1-3), 323-332.

Hammes, F., Goldschmidt, F., Vital, M., Wang, Y., Egli, T. (2010) Measurement and interpretation of microbial adenosine tri-phosphate (ATP) in aquatic environments. Water Res. 44 (13), 3915-3923.

Hellinga, C., Van Loosdrecht, M., Heijnen, J. (1999) Model based design of a novel process for nitrogen removal from concentrated flows. Mathematical and computer modelling of dynamical systems 5 (4), 351-371.

Hozalski, R. M., Bouwer, E., Bouwer, E. J. (2001) Non-steady state simulation of BOM removal in drinking water biofilters: applications and full-scale validation. Water Res. 35 (1), 211-223.

Hozalski, R., Goel, S., Bouwer, E. (1995) TOC removal in biological filters. Journal American Water Works Association 87 (12), 40-54. 
Hu, J. Y., Song, L., Ong, S., Phua, E., Ng, W., Song, L. F., Ong, S. L., Phua, E. T., Ng, W. J. (2005) Biofiltration pretreatment for reverse osmosis (RO) membrane in a water reclamation system. Chemosphere 59 (1), 127-133.

Huber, S. A., Balz, A., Abert, M., Pronk, W. (2011) Characterisation of aquatic humic and non-humic matter with size-exclusion chromatography - organic carbon detection - organic nitrogen detection (LC-OCD-OND). Water Res. 45 (2), 879-885.

Huck, P. (1999) Development of a framework for quantifying the removal of humic substances by biological filtration. Water Science and Technology 40 (9), 149-156.

Jaffe, R., McKnight, D., Maie, N., Cory, R., McDowell, W. H., Campbell, J. L. (2008) Spatial and temporal variations in DOM composition in ecosystems: The importance of long-term monitoring of optical properties. Journal of Geophysical Research-Biogeosciences 113 (G4), G04032.

Kaiser, K. and Benner, R. (2009) Biochemical composition and size distribution of organic matter at the Pacific and Atlantic time-series stations. Mar. Chem. 113 (1-2), 63-77.

Kumar, M., Adham, S. S., Pearce, W. R. (2006) Investigation of seawater reverse osmosis fouling and its relationship to pretreatment type. Environ. Sci. Technol. 40 (6), 2037-2044.

Lamsal, R., Walsh, M. E., Gagnon, G. A. (2011) Comparison of advanced oxidation processes for the removal of natural organic matter. Water Res. 45 (10), 3263-3269.

Lawaetz, A. J. and Stedmon, C. A. (2009) Fluorescence intensity calibration using the Raman scatter peak of water. Appl. Spectrosc. 63 (8), 936-940. 
Lorain, O., Hersant, B., Persin, F., Grasmick, A., Brunard, N. (2007) Ultrafiltration membrane pre-treatment benefits for reverse osmosis process in seawater desalting. Quantification in terms of capital investment cost and operating cost reduction. Desalination 203 (1-3), 277-285.

Matin, A., Khan, Z., Zaidi, S. M. J., Boyce, M. C. (2011) Biofouling in reverse osmosis membranes for seawater desalination: phenomena and prevention. Desalination 281, 1-16.

Ogawa, H. and Tanoue, E. (2003) Dissolved organic matter in oceanic waters. J. Oceanogr. 59 (2), 129-147.

Ogawa, H., Amagai, Y., Koike, I., Kaiser, K., Benner, R. (2001) Production of refractory dissolved organic matter by bacteria. Science 292 (5518), 917-920.

Parkash, S. (2003) Refining Processes Handbook. Gulf Professional Pub,

Pearce, G., Talo, S., Chida, K., Basha, A., Gulamhusein, A. (2004) Pretreatment options for large scale SWRO plants: case studies of UF trials at Kindasa, Saudi Arabia, and conventional pretreatment in Spain. Desalination 167 (1-3), 175-189.

Penru, Y., Simon, F. X., Guastalli, A. R., Esplugas, S., Llorens, J., Baig, S. (2011) Characterization of natural organic matter from Mediterranean coastal seawater. In: 4th IWA speciality coonference on Natural Organic Matter,

Rosberg, R. (1997) Ultrafiltration (new technology), a viable cost-saving pretreatment for reverse osmosis and nanofiltration - A new approach to reduce costs. Desalination 110 (1-2), 107-113. 
Salinas Rodriguez, S. G., Kennedy, M. D., Schippers, J. C., Amy, G. L. (2009) Organic foulants in estuarine and bay sources for seawater reverse osmosis Comparing pre-treatment processes with respect to foulant reductions. Desalination and Water Treatment 9 (1-3), 155-164.

Schneider, R., Ferreira, L., Binder, P., Bejarano, E., Goes, K. (2005) Dynamics of organic carbon and of bacterial populations in a conventional pretreatment train of a reverse osmosis unit experiencing severe biofouling. J. Membr. Sci. 266 (1-2), 18-29.

Schneider, S. H. and Mastrandrea, M. D. (2011) Encyclopedia of climate and weather. Oxford University Press, New York, 460 ; x, 479 ; x, 483.

Shon, H. K., Vigneswaran, S., Cho, J. (2008) Comparison of physico-chemical pretreatment methods to seawater reverse osmosis: Detailed analyses of molecular weight distribution of organic matter in initial stage. Journal of Membrane Science, 320 (1-2), 151-158.

Simon, F. X., Penru, Y., Guastalli, A. R., Llorens, J., Baig, S. (2011) Improvement of the analysis of the biochemical oxygen demand (BOD) of Mediterranean seawater by seeding control. Talanta 85 (1), 527-532.

Simon, F. X., Penru, Y., Guastalli, A. R., Esplugas, S., Llorens, J., Baig, S. (2012) NOM characterization by LC-OCD in a SWRO desalination line. Desalination and Water Treatment, 1-5.

Sndergaard, M. and Worm, J. (2001) Measurement of biodegradable dissolved organic carbon (BDOC) in lake water with a bioreactor. Water Res. 35 (10), 25052513. 
Søndergaard, M. and Middelboe, M. (1995) A cross-system analysis of labile dissolved organic-carbon. Marine Ecology Progress Series 118 (1-3), 283-294.

Standard Methods (1999) Standard methods for the examination of water and wastewater. American Water Works Association $<$ br / $>$. American Public Health Association, Washington, D.C.,

Tranvik, L. (1993) Microbial transformation of labile dissolved organic-matter into humic-like matter in seawater. FEMS Microbiol. Ecol. 12 (3), 177-183.

van der Kooij, D., Veenendaal, H., Baarlorist, C., Vanderlift, D., Drost, Y. (1995a) Biofilm formation on surfaces of glass and teflon exposed to treated water. Water Res. 29 (7), 1655-1662.

van der Kooij, D., Vrouwenvelder, H. S., Veenendaal, H. R. (1995b) Kinetic aspects of biofilm formation on surfaces exposed to drinking water. Water Science and Technology 32 (8), 61-65.

van Hoof, S., Hashim, A., Kordes, A. (1999) The effect of ultrafiltration as pretreatment to reverse osmosis in wastewater reuse and seawater desalination applications. Desalination 124 (1-3), 231-242.

Vial, D., Doussau, G., Galindo, R. (2003) Comparison of three pilot studies using Microza $<\mathrm{SUP}>{ }^{\circledR}</ \mathrm{SUP}>$ membranes for Mediterranean seawater pre-treatment. Desalination 156 (1-3), 43-50.

Volk, C. J., Volk, C. B., Kaplan, L. A. (1997) Chemical composition of biodegradable dissolved organic matter in streamwater. Limnol. Oceanogr. 42 (1), 39-44. 
Voutchkov, N. (2010) Considerations for selection of seawater filtration pretreatment system. Desalination 261 (3), 354-364.

Vrouwenvelder, J. S., Kappelhof, J. W. N. M., Heijman, S. G. J., Schippers, J. C., van der Kooij, D. (2003) Tools for fouling diagnosis of NF and RO membranes and assessment of the fouling potential of feed water. Desalination 157 (1-3), 361-365.

Vrouwenvelder, J. S. and van der Kooij, D. (2001) Diagnosis, prediction and prevention of biofouling of NF and RO membranes. Desalination 139 (1-3), 65-71.

Xu, J., Ruan, G., Chu, X., Yao, Y., Su, B. (2007) A pilot study of UF pretreatment without any chemicals for SWRO desalination in China. Desalination 207 (1-3), 216226.

Table 2. Characteristics of raw seawater

\begin{tabular}{c|c|c}
\hline Parameter & Unit & Value \\
\hline $\mathrm{pH}$ & - & $8.2 \pm 0.1$ \\
$\mathrm{TDS}$ & $\mathrm{g} \mathrm{NaCl} \mathrm{L}^{-1}$ & $32.5 \pm 0.6$ \\
Conductivity & $\mathrm{mS} \mathrm{cm}^{-1}$ & $57.4 \pm 0.4$ \\
$\mathrm{BOD}_{7}$ & $\mathrm{mg} \mathrm{O}_{2} \mathrm{~L}^{-1}$ & $1.11 \pm 0.32$ \\
$\mathrm{DOC}^{-1}$ & $\mathrm{mg} \mathrm{C} \mathrm{L}^{-1}$ & $0.96 \pm 0.11$ \\
$\mathrm{~A}_{254}$ & $\mathrm{~m}^{-1}$ & $0.67 \pm 0.03$ \\
Temperature & ${ }^{\circ} \mathrm{C}$ & $21 \pm 4$ \\
Turbidity & $\mathrm{NTU}$ & $1.06 \pm 0.28$ \\
\hline
\end{tabular}


Table 3. Characteristics of the column and packed bed

\begin{tabular}{c|c|c}
\hline Parameter & Units & Value \\
\hline height (h) & $\mathrm{mm}$ & 940 \\
diameter (d) & $\mathrm{mm}$ & 80 \\
h / d & - & 12 \\
bed volume & $\mathrm{L}$ & 4.7 \\
porosity & - & 0.4 \\
interfacial area & $\mathrm{m}^{-1}$ & 1,333 \\
bulk density & $\mathrm{kg} \mathrm{m}^{-3}$ & $0.73-0.90$ \\
\hline
\end{tabular}


Table 4. LC-OCD fraction composition

\begin{tabular}{c|c|c}
\hline Fraction & Size Range (Da) & Composition \\
\hline Biopolymers & $>20,000$ & Polysaccharides and protein \\
Humic substances & $\sim 1,000$ & Humic and fulvic acids \\
Building blocks & $300-500$ & Weathering and oxidation products of humics \\
LMW neutrals & $<350$ & Alcohols, aldehydes, ketones and amino acids \\
LMW organic acids & $<350$ & Aliphatic low-molecular-weight organic acids \\
\hline
\end{tabular}


Table 5. Fluorescence regions (accordingly to Chen et al., 2003)

\begin{tabular}{c|c|c|c}
\hline Region & Excitation & Emission & Description \\
\hline I & $220-250$ & $280-332$ & Aromatic proteins I \\
II & $220-250$ & $332-380$ & Aromatic proteins II \\
III & $220-250$ & $380-580$ & Fulvic acid-like \\
IV & $250-470$ & $280-380$ & Microbial by-products \\
V & $250-470$ & $380-580$ & Humic acid-like \\
\hline
\end{tabular}


Table 6. Inlet and outlet concentrations of the different analytical parameters and the removals attained in the biofiltration process

\begin{tabular}{|c|c|c|c|c|c|c|c|c|c|}
\hline \multirow{2}{*}{ Parameter } & \multicolumn{3}{|c|}{$\begin{array}{c}\text { Experiment } 1 \\
\text { EBCT }=5.7 \mathrm{~min}\end{array}$} & \multicolumn{3}{|c|}{$\begin{array}{c}\text { Experiment } 2 \\
\text { EBCT }=8.1 \text { min }\end{array}$} & \multicolumn{3}{|c|}{$\begin{array}{c}\text { Experiment } 3 \\
\text { EBCT }=11.3 \mathrm{~min}\end{array}$} \\
\hline & INLET & OUTLET & $\begin{array}{c}\text { Removal } \\
{[\%]}\end{array}$ & INLET & OUTLET & $\begin{array}{c}\text { Removal } \\
{[\%]}\end{array}$ & INLET & OUTLET & $\begin{array}{c}\text { Removal } \\
{[\%]}\end{array}$ \\
\hline $\begin{array}{c}\text { DOC } \\
{\left[\mathrm{mg} \mathrm{C} \mathrm{L}^{-1}\right]}\end{array}$ & $\begin{array}{c}0.94 \\
( \pm 0.10)\end{array}$ & $\begin{array}{c}0.88 \\
( \pm 0.11)\end{array}$ & 6 & $\begin{array}{c}1.13 \\
( \pm 0.06)\end{array}$ & $\begin{array}{c}1.07 \\
( \pm 0.05)\end{array}$ & 5 & $\begin{array}{c}0.93 \\
( \pm 0.08)\end{array}$ & $\begin{array}{c}0.87 \\
( \pm 0.07)\end{array}$ & 6 \\
\hline $\begin{array}{c}\mathbf{A}_{254} \\
{\left[\mathrm{~m}^{-1}\right]}\end{array}$ & $\begin{array}{c}0.68 \\
( \pm 0.03)\end{array}$ & $\begin{array}{c}0.65 \\
( \pm 0.04)\end{array}$ & 4 & $\begin{array}{c}0.65 \\
( \pm 0.02)\end{array}$ & $\begin{array}{c}0.61 \\
( \pm 0.02)\end{array}$ & 6 & $\begin{array}{c}0.68 \\
( \pm 0.04)\end{array}$ & $\begin{array}{c}0.64 \\
( \pm 0.04)\end{array}$ & 6 \\
\hline $\begin{array}{c}\mathrm{BOD}_{7} \\
{\left[\mathrm{mg} \mathrm{O}_{2} \mathrm{~L}^{-1}\right]}\end{array}$ & $\begin{array}{c}1.10 \\
( \pm 0.21)\end{array}$ & $\begin{array}{c}0.94 \\
( \pm 0.21)\end{array}$ & 15 & $\begin{array}{c}1.11 \\
( \pm 0.26)\end{array}$ & $\begin{array}{c}0.98 \\
( \pm 0.32)\end{array}$ & 12 & $\begin{array}{c}1.00 \\
( \pm 0.23)\end{array}$ & $\begin{array}{c}0.88 \\
( \pm 0.20)\end{array}$ & 12 \\
\hline $\begin{array}{c}\text { SUVA } 254 \\
{\left[\mathrm{~L} \mathrm{mg} \mathrm{C}^{-1} \mathbf{~ m}^{-1}\right]}\end{array}$ & 0.72 & 0.74 & -2 & 0.58 & 0.57 & 1 & 0.73 & 0.74 & -1 \\
\hline $\begin{array}{c}\mathrm{BOD}_{7} / \mathrm{DOC} \\
{\left[\mathrm{mg} \mathrm{O}_{2} \mathrm{mg} \mathrm{C}^{-1}\right]}\end{array}$ & 1.17 & 1.07 & 9 & 0.98 & 0.92 & 7 & 1.08 & 1.01 & 6 \\
\hline
\end{tabular}


Table 7. Fluorescence intensity distribution at the inlet and outlet streams of the biofilter and removals operating at EBCT $=8.1 \mathrm{~min}$

\begin{tabular}{c|c|c|c}
\hline Fractions & $\begin{array}{c}\text { INLET } \\
\boldsymbol{\Sigma} \text { int [R.U.] } \\
\text { (Distribution, \%) }\end{array}$ & $\begin{array}{c}\text { OUTLET } \\
\boldsymbol{\Sigma} \text { int [R.U.] } \\
\text { (Distribution, \%) }\end{array}$ & $\begin{array}{c}\text { Removal } \\
{[\%]}\end{array}$ \\
\hline I - Aromatic Protein I & 132 & 105 & 21 \\
II - Aromatic Protein II & 404 & 361 & 11 \\
\hline III - Fulvic acid-like & $(7)$ & $(8)$ & 11 \\
\hline IV - Microbial by-product & 3603 & 3215 & 14 \\
\hline V - Humic acid-like & $(66)$ & $(67)$ & 14 \\
\hline TOTAL & $(2)$ & 69 & 12 \\
\hline
\end{tabular}



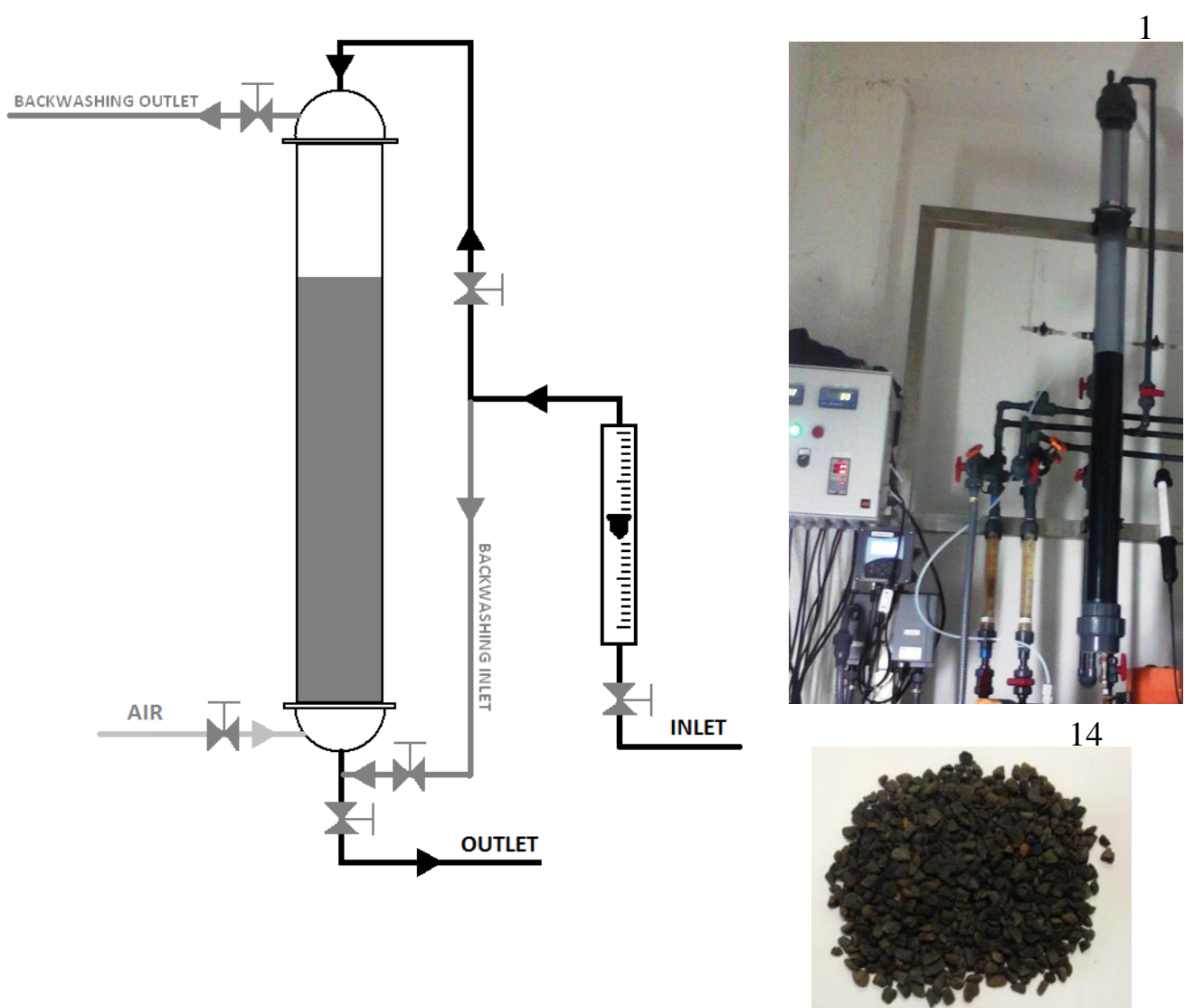

(c)

Figure 10. (a) Scheme of the biofiltration pilot; (b) Image of the pilot plant; (c) Expanded clay - Biolite $® L 2.7$ 


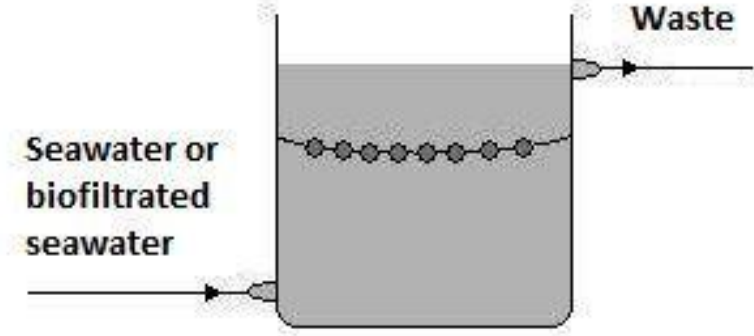

Figure 11. Scheme of the BFC monitor 


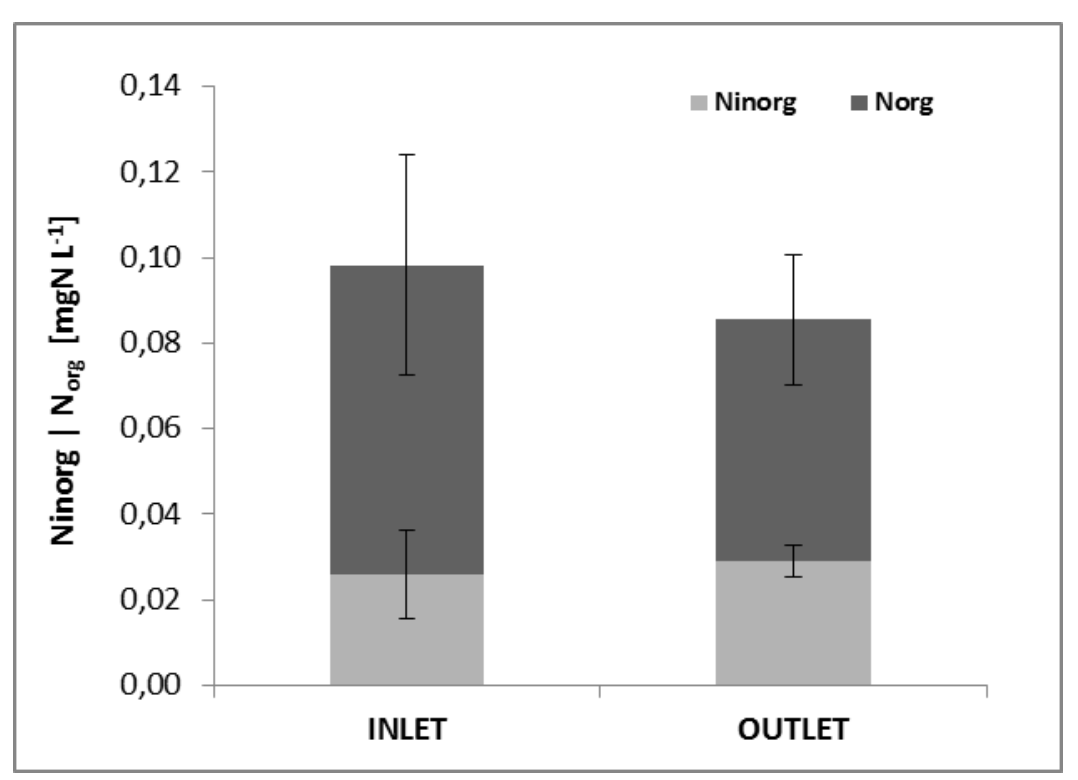

Figure 12. Concentration of $\mathrm{N}_{\text {inorg }}$ and $\mathrm{N}_{\text {org }}$ at the inlet and outlet streams of the biofilter operating at $\mathrm{EBCT}=8.1 \mathrm{~min}$ 


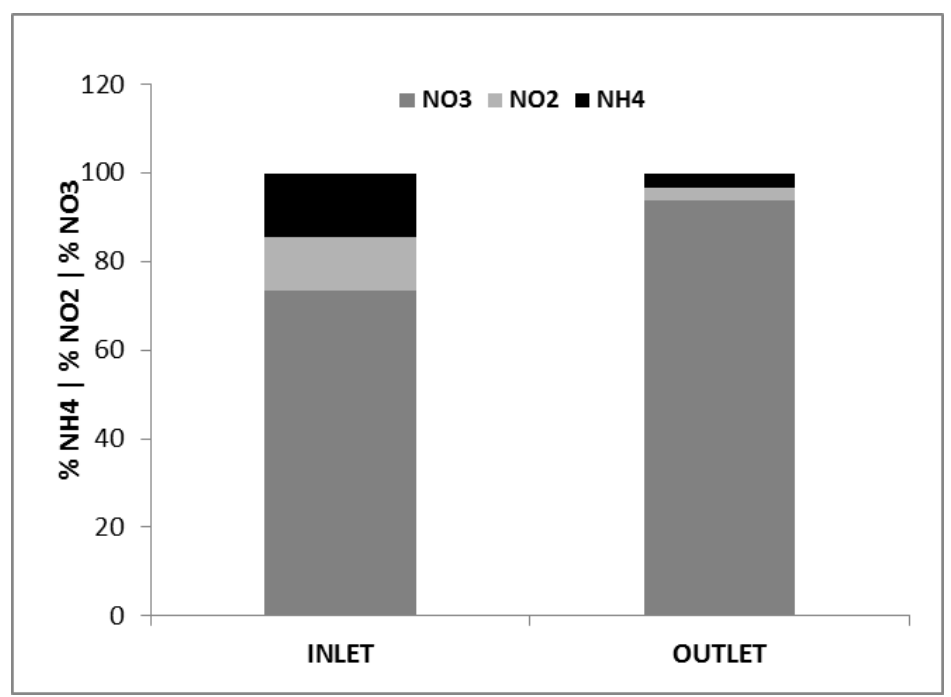

Figure 13. Inorganic nitrogen $\left(\mathrm{NH}_{4}{ }^{+}, \mathrm{NO}_{2}{ }^{-}, \mathrm{NO}_{3}{ }^{-}\right)$distribution in the inlet and outlet streams of the biofilter operating at $\mathrm{EBCT}=8.1 \mathrm{~min}$ 


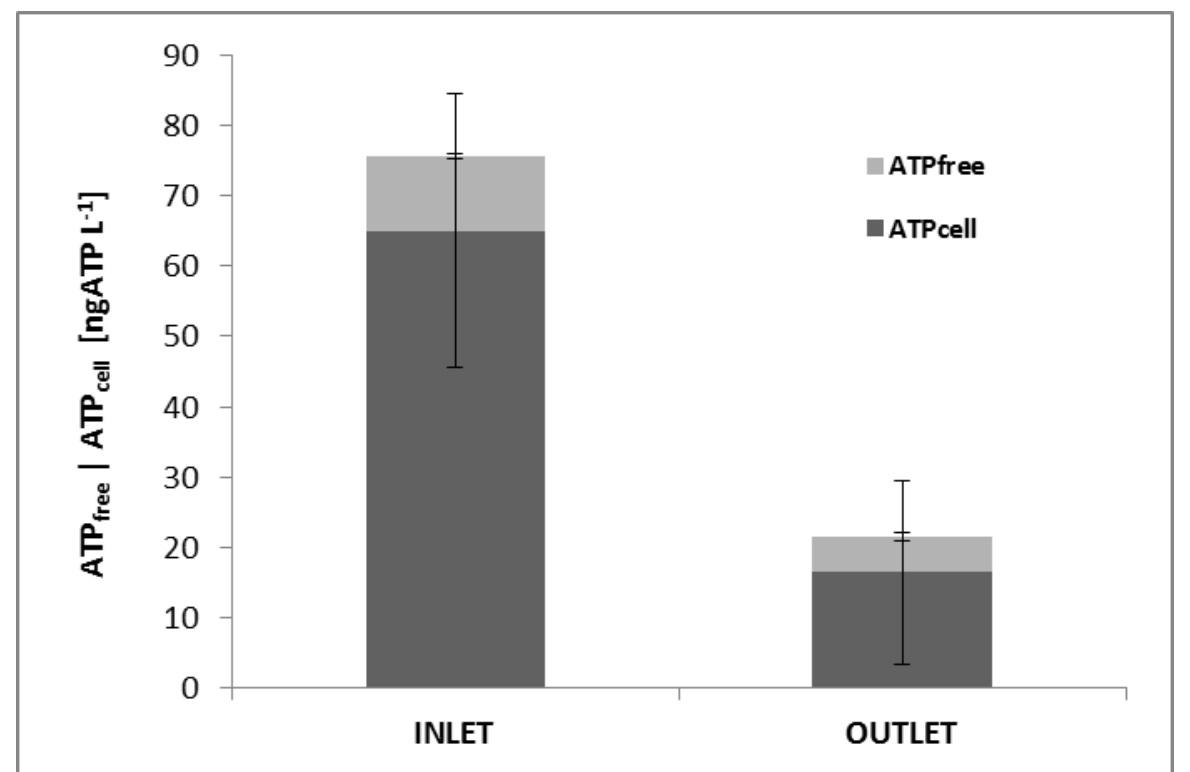

Figure 14. Concentrations of $\mathrm{ATP}_{\text {cell }}$ and $\mathrm{ATP}_{\text {free }}$ at the inlet and outlet streams of the biofilter operating at $\mathrm{EBCT}=8.1 \mathrm{~min}$. 


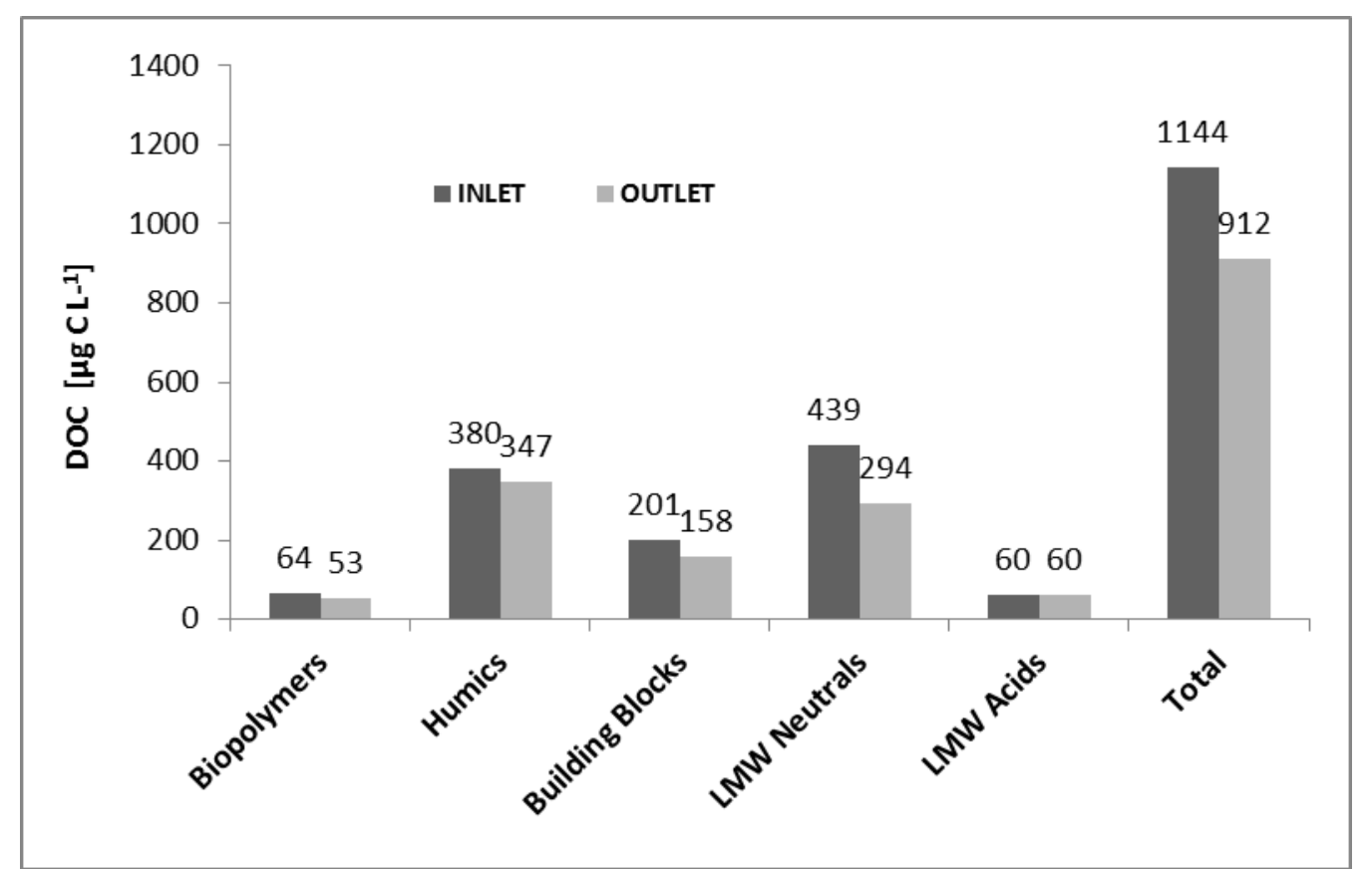

Figure 15. Results of LC-OCD for the inlet and outlet streams of the biofilter operating at EBCT $=8.1 \mathrm{~min}$ 


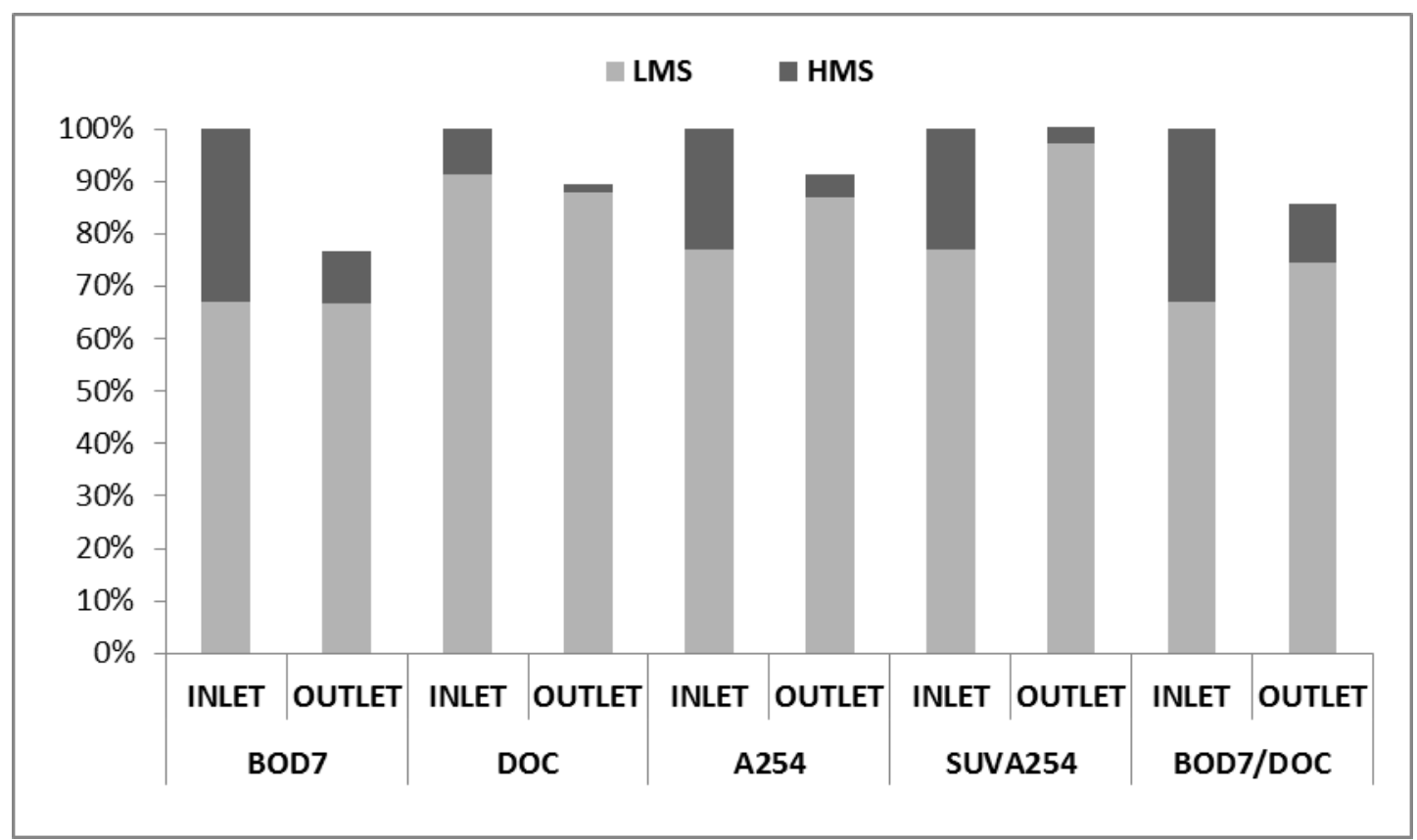

Figure 16. LMS and HMS fractions distribution at the inlet and outlet streams of the biofilter, expressed in terms of $\mathrm{BOD}_{7}$, $\mathrm{DOC}$, and $\mathrm{A}_{254}(\mathrm{EBCT}=8.1$ min). Note that in case of the outlet stream the distribution between LMS and HMS is referred to inlet parameters. 

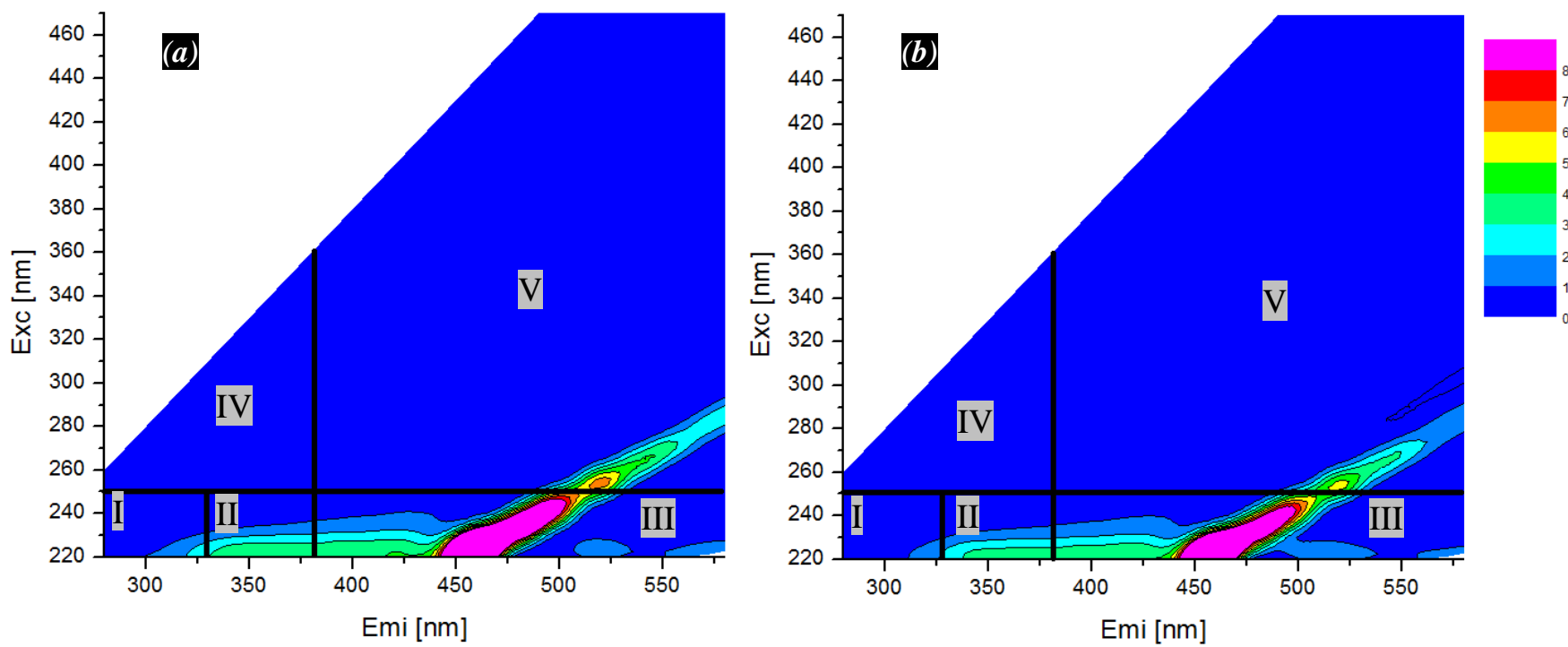

Figure 17. Density plots of fluorescence intensities for seawater at the input $(a)$ and output $(b)$ of the biofilter $(\mathrm{EBCT}=8.1 \mathrm{~min})$ 


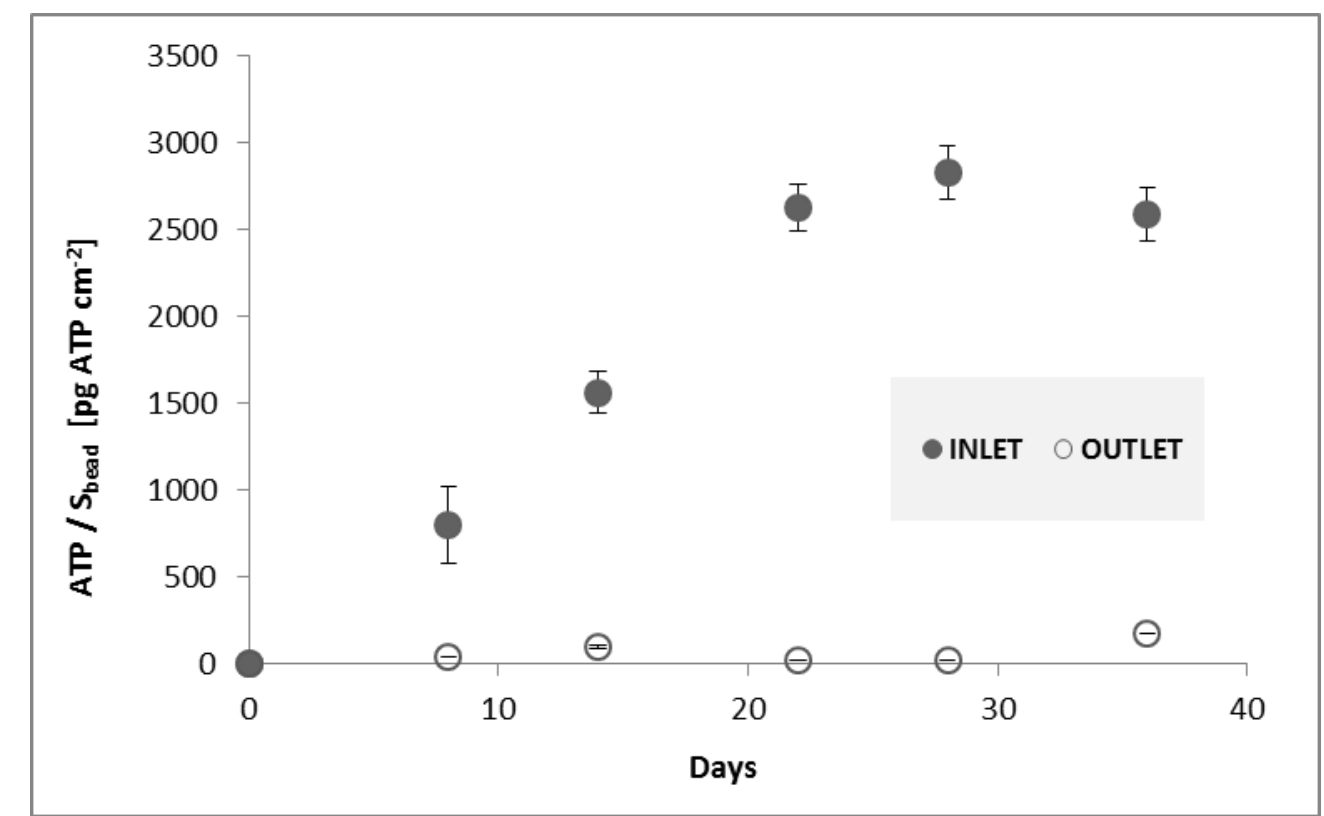

Figure 18. ATP concentrations on the surface of the beads versus time obtained with the assay BFC performed in the seawater before (inlet) and after (outlet) of biofiltration process $(\mathrm{EBCT}=8.1 \mathrm{~min})$ 